\title{
'Il y a des larmes dans leurs chiffres': French Famine Relief for Ireland, 1847-84
}

"Il y a des larmes dans leurs chiffres ": L'assistance alimentaire française à

l'Irlande, 1847-1884

\section{Grace Neville}

\section{OpenEdition}

\section{Journals}

Electronic version

URL: http://journals.openedition.org/rfcb/261

DOI: $10.4000 / \mathrm{rfcb} .261$

ISSN: 2429-4373

\section{Publisher}

CRECIB - Centre de recherche et d'études en civilisation britannique

Printed version

Date of publication: 1 September 2014

Number of pages: 67-89

ISSN: 0248-9015

\section{Electronic reference}

Grace Neville, "'Il y a des larmes dans leurs chiffres': French Famine Relief for Ireland, 1847-84 ", Revue Française de Civilisation Britannique [Online], XIX-2 | 2014, Online since 01 May 2015, connection on 01 May 2019. URL : http://journals.openedition.org/rfcb/261 ; DOI : 10.4000/rfcb.261

\section{cc) (†) $\odot$}

Revue française de civilisation britannique est mis à disposition selon les termes de la licence Creative Commons Attribution - Pas d'Utilisation Commerciale - Pas de Modification 4.0 International. 


\title{
'Il y a des larmes dans leurs chiffres': French Famine Relief for Ireland, 1847-84
}

\author{
Grace NEVILLE \\ University College Cork, National University of Ireland
}

In July 1934, near the little County Cork village of Araglin, an elderly farmer, Michael Donegan, in conversation with a collector from the Irish Folklore Commission, illustrated the cruelty of a local landlord, Collins, with the following anecdote:

In the famine times 1847 there was fourteen barrels of biscuits thrown out in the dung at his place and the people starving with hunger around the place. The French sent several cargoes of biscuits to relieve the poor. These biscuits were consigned to the guardians of the people and it was Collins and his equals that were the guardians. ${ }^{1}$

The farmer in question may well have been unable to pinpoint France on a map of the world, yet he could identify it as the place that sent food to his starving community when they needed it most. The ancestral memory of hunger, lodged in his heart and in his mind and in his bones, seems forever associated for him with the generosity of a faraway people, the French, and with the manner in which it was literally rubbished through the hardheartedness of a local landlord.

Given strong Irish presence throughout the English-speaking world, it is not surprising that famine relief for Ireland from these regions was substantial and that it has attracted serious scholarly attention. ${ }^{2}$ This is not the case with famine relief sent from elsewhere, despite its importance and the abiding memories it clearly left. This study is based on a close reading of the writings of French clerics who appealed for famine relief for Ireland between the 1840s and the 1880s. These writings can be divided into three phases: 1847, 1861-62 and 1880. The texts are both oral and written, and consist of twenty-one letters (between one and sixteen pages long) that were to be read to churchgoers, in addition to three lengthy sermons that were to be printed and sold. Their intended audience was immense and covered the entire Catholic community of France, from Parisian high society to illiterate people in all corners of the country. The urgent message they so vividly convey harnesses a powerful alliance of heart and head, emotion and intellect: as Gaspard Mermillod,

\footnotetext{
${ }^{1}$ I am grateful to Coimisiun Bealoideasa Eireann for permission to use this quotation from its archives.

${ }^{2}$ See especially Christine KINEALY, Charity and the Great Hunger in Ireland, London: Bloomsbury, 2013.
} 
author of one of the sermons discussed below, quips: 'il y a des larmes dans leurs chiffres'.

Even today, knowledge of famine in Ireland is often limited to the Great Famine of the 1840s. From the seventeenth century onwards, however, French writers on Ireland demonstrate a keen awareness of Ireland as a land not of famine but of relentless, never-ending cycles of famine. ${ }^{3}$ Indeed, French newspaper readers had long been aware of Ireland as 'le pays classique de la faim' ${ }^{4}$ from years before the catastrophe of the 1840s. To take just one perhaps unexpected example, in the Rhône-Alpes region alone, for the period 1812-60, twenty-two local newspapers carried the story of famine in Ireland in a total of 399 articles, some on the front page and featuring graphic accounts of the famine-stricken Irish. Most but by no means all of these accounts cluster around the period 1845-48. ${ }^{5}$ Similarly, in the years leading up to the Great Famine, famine in Ireland caught the attention of writers like Adolphe Garnier, ${ }^{6}$ a Paris lawyer, Léon Galibert and Clément Pellet, ${ }^{7}$ two editors of the prestigious Revue britannique, and de Tocqueville's friend and travelling companion, Gustave de Beaumont. ${ }^{8}$ That famine in Ireland did not end with the Great Famine was similarly obvious to commentators from the 1850s and 1860s, including le Vicomte Joseph-Alexis Walsh, ${ }^{9}$ Louis Blanc and Jules de Lasteurie: the title of the latter's article, 'L'Irlande depuis la dernière famine', surely says it all. ${ }^{10}$

Just as French awareness of famines in Ireland predates the 1840s, so too was French help for the starving Irish activated well before the Great Famine. Shortly after his visit to Ireland in 1830, realising that famine had erupted there once more, Montalembert organised a collection among the French Catholic public through his newspaper, L'Avenir. In just three months, his appeal produced 80,000 francs. Indeed, the Irish branch of the St Vincent de Paul Society regularly contacted the organisation's head office established in Paris in 1833 to alert sympathetic countries in which the Society was established in order to raise funds for the starving Irish. ${ }^{11}$

\footnotetext{
3 See Grace NEVILLE, 'Remembering and Forgetting the Great Famine in France and Ireland', New Hibernia Review, vol. 4, no. 16, winter 2012, pp. 80-94.

${ }^{4}$ Louis BLANC, Lettres sur l'Angleterre, Paris : A. Lacroix, Verboeckhoven et cie, 1866, vol. 2, p. 334.

5 See : <http://www.memoireetactualite.org/fr/presse_resultats.php?rs_kw=irlande+famine \& searchtype $=\mathrm{s}>$.

${ }^{6}$ Adolphe GARNIER, De la peine de mort, Paris: Imprimerie de Guiraudet, 1827, p. 85.

${ }^{7}$ Léon GALIBERT and Clément PELLET, Angleterre, Ecosse et Irlande, Paris: Firmin, Didot frères, 1844.

${ }^{8}$ Gustave de BEAUMONT, L'Irlande sociale, politique et religieuse, Paris: Michel Levy frères, 1839 .

${ }^{9}$ Joseph Alexis le Vicomte WALSH, Yvon le Breton ou souvenirs d'un soldat des armées catholiques et royales, Paris: J. Vermot, 1854, p. 287.

${ }^{10}$ Jules de LASTEURIE, 'L'Irlande depuis la dernière famine', Revue des deux mondes, August 1853.

${ }^{11}$ See Maire Brighid NI CHEARBHAILL, 'The Society of St Vincent de Paul in Dublin, 1926-1976', PhD dissertation, National University of Ireland, Maynooth, 2008.
} 


\section{7}

This wider framework, therefore, helps to contextualise the appeals by French clerics for aid for the famine-stricken Irish made from 1847 to $1880 .^{12}$ The particular trigger for the 1847 appeals was a gesture by Pope Pius IX: on 25 March of that year, the first year of his pontificate, at the Basilica di Santa Maria Maggiore, Rome, he took the rare step of issuing an encyclical, Praedecessores Nostros, entreating Catholics world-wide to offer prayers and alms for the starving Irish. ${ }^{13}$ In it, he establishes his appeal within the age-old Papal practice of calling for spiritual and temporal relief for Christians in their hour of need. He explains that he had already called for public prayers for Ireland in Rome and sent monies collected to the archbishops of Ireland. However, recent letters received from Ireland and daily news updates now inform him that the situation there is worsening. He reminds his audience that Ireland has always stood firm in its Catholicism and has long spread the gospel far and wide. Therefore, having sought advice from his cardinals, he is now taking the additional step of penning this encyclical. Specifically, he calls for the measures already taken in Rome to be followed by all: three days of public prayers are to be said in return for various indulgences; alms are to be collected.

His call was heard loud and clear in France where it quickly prompted the leaders of the Catholic Church to issue letters requesting the clergy of their dioceses to bring the Pope's call to the attention of their parishioners. The National Library of Ireland in Dublin holds a cache of seventeen of these letters. Each was written by a bishop, archbishop or cardinal, including the Archbishop of Paris, Denis Auguste Affre, and most incorporate the Pope's text. Each is distinctive in both content and form, yet all converge in relaying the Pope's stark message: the Irish are starving and need your help.

The widespread notoriety of the famine currently devastating Ireland is actually highlighted by the almost throwaway fashion in which it is noted. The very first line of the letter by the Bishop of Strasbourg reads: 'Vous connaissez, nos trèschers Frères, les maux affreux qui pèsent sur l'Irlande'. The Bishop of Metz similarly acknowledges that he is telling his audience nothing new: 'Personne d'entre vous n'ignore l'horrible détresse où est réduit ce Royaume infortuné. The clerics list their sources of information: 'les feuilles publiques, la correspondance des évêques, les récits des voyageurs, les lettres particulières, ont fait parvenir jusqu'à nous de douloureux détails sur les ravages que la famine y cause chaque jour' (Bordeaux).

The information they have garnered compels them to present Ireland as an exceptional case, a land of the most dramatic, unheard of ('inouïs', Angers) extremes: 'infortunes, violences, persécutions, humiliations de toutes sortes, rien ne lui a manqué' (Limoges). However, the famine of this year of 1847 is worse than anything experienced to date. Therefore, the Bishop of Nancy and Toul starts his letter in these dramatic terms: 'Depuis longtemps des cris de détresse sont partis de l'Irlande; mais ces cris ont redoublé pendant cette année, et l'on compte par

${ }_{12}^{12}$ Please see appendix 1 for a list of these 17 letters.

${ }^{13}<$ www.papapencyclicals.net/Pius09/p9praede.htm> 
milliers les victimes que la faim moissonne chaque jour au sein d'un peuple hérö̈que et malheureux'. In short, the current famine is nothing less than 'la plus grande affliction que l'histoire des temps modernes nous ait présentée' (Bordeaux). Detailed information on inter alia famine fever and workhouses show that these writers were very well informed of the situation under discussion. They are at pains to select the most poignant images of famine in order to move their audiences: mothers with no milk for their children; crowds of starving, ragged people wandering the silent countryside fighting with animals for plants to eat; 'ces cités désertes, qu'on dirait peuplées de fantômes' (Limoges); 'ils errent comme des spectres, pâles et livides, dans les campagnes et les villes, implorant la pitié publique' (Angers). Vocabulary seems deliberately chosen in order to shock the French faithful into disbursing alms for the Irish: Ireland is now 'un vaste tombeau, dans lequel étaient ensevelis, chaque jour, des milliers d'infortunés, moissonnés par la fièvre et la famine' (Carcassonne).

Disaster piles on top of disaster in this unfortunate country. Further difficulties include the rise of proselytism. And to make a bad situation even worse, as the Bishops of Strasbourg and Beauvais note, comes the recent blow of Daniel O'Connell's death. So well-known is O'Connell that several writers here do not even need to mention him by name: everyone knew who is being praised and mourned. A remarkable comment in the text of Cardinal de Bonald of Lyon and Vienne, dated 2 August 1847, indicates that it had been hoped that O'Connell's body would be received in Lyon; since this would now not happen, at least prayers and alms could be sent to his compatriots. A more poignant reference to O'Connell comes in the letter of the Bishop of Bordeaux, dated 13 May 1847, which reveals that he is clearly aware of O'Connell's journey to Rome that was taking place at that very moment. The Bishop addresses himself directly to Ireland whom he hails as 'tu': 'Puisse-t-il trouver, dans les hommages dont l'entoure la France catholique, et surtout à Rome, aux pieds du suprême consolateur, les forces qu'il serait heureux de te consacrer jusqu'à son dernier soupir!' A mere two days later, O'Connell was to die in Genoa, having traversed France, without ever reaching his destination.

Threaded through these 1847 letters is a revealing commentary on the material difficulties currently assailing France. Many writers express their reluctance and awkwardness to ask for alms for Ireland given the disastrous year the French faithful have just endured. Here as elsewhere, strong language is used: the Bishop of Le Mans sympathises with his flock who have already made offerings this year: "vos âmes sensibles ont été péniblement affectées et souvent déchirées, dans le cours de cette année, par les spectacles d'affligeantes misères'. Thus, the Bishop of Perpignan explains his pragmatic decision to delay for four months before bringing the Pope's message to his faithful in early August:

le temps en effet ne nous paraissait pas alors favorable: l'inondation de la Loire, les rigueurs de l'hiver [...] avaient, avec succès, provoqué vos largesses; puis, la récolte était à faire: incertain de ses résultats, préoccupé par la pensée qu'elle pouvait être mauvaise et vous laisser encore dans la gêne, nous résolûmes de ne vous transmettre qu'après la moisson les lettres apostoliques. 
Rising food prices and the threat of famine in a land of plenty - France this time - are mentioned. Indeed, like the Pope, the Bishop of Le Mans refers indirectly to the threat of famine spreading: 'N'oublions pas que le terrible fléau qui éprouve si cruellement la pauvre Irlande peut nous atteindre aussi bien qu'elle'. However, as the Bishop of Beauvais intimates, these woes cannot be compared to those of Ireland; in any case, now that France seems spared, at least momentarily, attention can turn to the starving Irish.

Why should the French faithful send famine relief to Ireland? The leaders of the French Church here provide numerous arguments. Many insist that the Catholic Church is first and foremost a family, with its earthly father, the Pope, in Rome, and its siblings closely bound though scattered far and wide. Consequently, they have a non-negotiable responsibility to help their ailing family member, Ireland. Political considerations surface too. The invitation to help the Irish presents France with an opportunity to command the high moral ground vis-à-vis the English. Cardinal de Bonald of Lyon and Vienne suggests that if England refuses freedom to Ireland, at least the French can intervene by helping the Irish poor. A different twist on this theme is provided from the other side of the Atlantic in a text that actually predates Pius IX's appeal: on 19 February 1847, the Bishop of Montreal sent a circular to the clergy of his dioceses begging for famine relief for the starving Irish and Scottish. Appeals emanating from France often explain solidarity between France and Ireland as resulting from shared adversity to a common enemy, England; the Montreal prelate sees things differently: for him, what the people now in need and those from whom he is requesting alms share is common membership of the British empire and, in many cases, a common birth place too. ${ }^{14}$

Other perhaps less altruistic reasons are advanced. Several bishops suggest that helping others (in this case the Irish) will ward off bad luck and ensure a continuation of good fortune, for instance in the form of rich harvests:

vous qui avez beaucoup reçu de l'auteur de tout don, à votre tour, donnez à ceux de vos frères qui souffrent loin de vous [...] Donnez, donnez largement, N. T. C. F., et le Bon-Dieu éloignera de vous les fléaux qui nous ont tant affligés, ces dernières années, et ceux qui nous menacent peut-être encore dans l'avenir. (Pamiers)

Nor can a certain feel-good factor be overlooked here. The sixteen-page letter of the Bishop of Limoges is particularly interesting in this respect:

Nous pouvons être fiers, pour notre part, du rôle que Dieu a tracé dans cette grande mission de l'Eglise militante. La France, par l'ardeur de sa foi, l'activité de son génie, l'héroüsme de son courage, le privilège de sa langue universelle, mérita une initiative glorieuse dans la

\footnotetext{
${ }^{14}$ Later letters from Montreal and Quebec did echo the Pontiff's call: see Lettre pastorale de Monseigneur l'Evêque de Montréal pour publier l'encyclique de Notre Saint père le Pape Pie IX en faveur de la malheureuse Irlande, Montreal, 1847; on 14 June 1847, Joseph Signay, Archbishop of Quebec, addressed a letter to everyone in his dioceses publicising the papal call for help for the starving Irish.
} 
propagation de la Foi catholique, et porta au loin les pacifiques conquêtes de Jésus-Christ; soldat par sa valeur guerrière, apôtre par la rapide diffusion de sa parole, le peuple français est l'avant-garde de l'Eglise, de la civilisation et du progrès; il combat pour étendre le catholicisme, comme d'autres peuples souffrent et meurent pour le glorifier.

This militaristic tone permeates his entire text, with descriptions of the teeth of lions and axes of executioners spilling the blood of early Christians; their spiritual descendants are the Irish whose history is a holocaust etched in blood. This, giving alms to the Irish somehow strengthens his vision of the Catholic Church (in France and elsewhere) as the Church militant.

How is this famine relief operation to be organised? It has already begun elsewhere as Ireland's plight has by now touched hearts all around the world ('le monde entier s'en est ému', Pamiers). The Bishop of Carcassonne notes that monies are being collected 'dans les deux Continents', while the Bishop of Angers adds: 'déjà sur tous les points de la chrétienté, des comités se sont organisés, des quêtes ont été faites, et l'obole du pauvre s'est rencontrée avec la pièce d'or du riche'. The implication is clear: now is the time for France to step forward and perhaps to surpass largesse witnessed elsewhere.

Comprehensive instructions are given. The episcopal letter is to be read in all churches and chapels in the dioceses. Particular prayers for Ireland are to be offered on specified dates: 'les dimanche, lundi et mardi 19, 20 et 21 du mois de décembre prochain, il sera fait des prières publiques pour l'Irlande, dans toutes les églises de notre diocèse' (Pamiers). Detailed information follows on the various indulgences, including plenary indulgences, that the faithful can thereby earn.

How and when are monies to be collected? Instructions are exhaustive, down to specifications for the type of receptacle in which alms are to be placed: ' $O n$ pourra déposer ces aumônes le jour de l'Assomption dans le bassin qu'on fera passer dans l'Eglise où qu'on placera à la porte pour les recevoir' (Mende). In Perpignan, 'le dimanche, 14 novembre, il sera fait, à l'office du matin et du soir, exclusivement à toute autre, une quête pour les malheureux Irlandais; [...] il en sera rendu compte au prochain mandement du Carême'. In Paris, offerings are to be entrusted to the local priests or to the head of the Collège des Irlandais; these offerings in turn to be forwarded to a named person, M. de Barante, 'Trésorier de l'Association', at 8 rue Garancière, who has been charged with distributing them among the Irish dioceses. In Bordeaux, monies may be sent via the President of the St Vincent de Paul Society at 12 rue Rohan. The Bishop of Beauvais remains nonetheless concerned about his parishioners' ability to pay: if a general collection would not be appropriate given the slender resources of the faithful in these difficult times, then his priests will invite their richer parishioners to offer alms for the Irish.

Among the acknowledged sources of the remarkably up-to-date information flowing from Ireland to France in the 1847 texts discussed above are letters from Irish bishops. In fact, in 1847, the Imprimerie d'A. Sirou et Desquers in Paris published a fifteen page booklet of extracts of letters sent in that same year by 
thirteen bishops and archbishops around Ireland to Monsieur O'Carroll, described as 'correspondent du Comité de Secours' active in collecting French alms for Ireland. ${ }^{15}$ These letters acknowledge with heartfelt thanks the monies and correspondence already sent by France. They provide an update on the situation: in Belfast, three thousand people are currently destitute. Hunger and typhus are particularly bad in the west as crops have not been sown, government work schemes are few and locations are isolated. The Bishop of Dromore conveys a strong sense that his dioceses is poised on brink of disaster as soup and flour rations are about to run out. From Castletown-Berehaven in west Cork, a parish priest, Fr Enright, warns of proselytisers and pleads for money for his schools to 'arracher' Catholic children from well-endowed Protestant schools:

les écoles nationales étaient abandonnées, tandis que les pensionnats protestants, où les enfants sont nourris et habillés, avaient plus d'élèves qu'ils n'auraient dî en recevoir. Le nombre de nos paroissiens diminuait sensiblement, tandis que les ministres hérétiques voyaient augmenter celui de leurs adeptes en proportion de nos pertes. Il faut l'avouer, les ministres protestants, aidés par le fléau, n’ont malheureusement que trop profité du triste avantage de leur position!

Like others, he appeals directly to France: 'Oh! France, reine des Eglises chrétiennes, ta charité est encore restée inépuisable! L'esprit de saint Vincent de Paul plane toujours sur toi et t'inspire les oeuvres de miséricorde!'. All that can be offered in return for French aid are Irish prayers.

The detailed results of this 1840 s French famine relief drive are outlined in an eight-page French report addressed to the bishops and archbishops of France and to the members of the 'Comite de l'Irlande'. ${ }^{16}$ Its preamble replaces famine in Ireland within the wider - particularly French - context with potato crop failures and looming food shortages following flooding in the Loire. In Ireland itself, the situation was particularly dramatic, we are told, with the potato harvest collapsing for a second year, and a famished people being savaged by starving dogs. Following the Pope's appeal, we read that a committee established in Paris collected the impressive sum of 500,861 francs which it sent to the bishops and archbishops of Ireland via M. O'Carroll, here described as the president of the 'Conférences de Saint-Vincent-de-Paul d'Irlande'. Pride is expressed that, despite various difficulties, Catholic France was able to achieve so much: 'quelle consolation pour nos cours de penser que le denier de la France a été placé à si gros intérêt'. There follows a remarkable list of the amounts sent by sixty-seven dioceses (including the non-French dioceses of Annecy and Chambery in Savoie, Ivrée in Piedmont, SaintGallen in Switzerland, Sassari in Sardinia, Aix-la-Chapelle/Aachen in Prussia and Tournai in Belgium). The individual sums range from 47 francs from Coutances to 33,338 francs from Lyon and 49,985 francs from Paris. This account is detailed to

${ }^{15}$ Extraits de quelques lettres de NN. SS. Les archevêques et évêques d'Irlande, à Monsieur O'Carroll, correspondent du Comité de Secours, Paris: Imprimerie d'A. Sirou et Desquers, 1847.

${ }^{16}$ Rapport à Messigneurs les archevêques et évêques de France et à messieurs les membres du Comité d'Irlande, Paris: Imprimerie de Jules-Judeau, 1849. 
the extent of specifying even bank and administration charges, along with postal difficulties. Of particular interest is the mention of 5,640 francs collected in the Cathédrale de Notre-Dame, Paris, following the funeral oration preached there by Lacordaire on 10 February 1848 in memory of Daniel O'Connell. Intercalated in this report is a two-page facsimile of a handwritten letter dated September 1849 and signed on behalf of the Irish Committee by three people including Montalembert. Its reference to the first meeting of the Committee taking place on 24 July 1847 in the Paris Archbishopric is an interesting example of the seriousness afforded the Great Irish Famine in high places in France even as it was unfolding.

\section{1-62}

In the early 1860s, less than two decades after the devastation and trauma of the Great Famine, alarm bells once more rang out across France summoning the French faithful to come to the aid of the Irish yet again facing another famine compounded by a difficult winter and incessant rains. The most powerful responses this time came in the form of two lengthy sermons preached in Paris churches in 1861 and 1862 by two leading clerics, accompanied by a collection organised by aristocrats and society members. These sermons were then printed and offered for sale for the benefit of impoverished Irish Catholics. The first was by renowned orator, Félix Dupanloup (1802-78), Bishop of Orléans and member of the Académie Française, whose strong links with Ireland were to continue through the FrancoPrussian war of 1870-1. The two and a half hour sermon was preached in the very heart of Paris, in the first arrondissement, at the Eglise Saint-Roch, on the Feast of the Annunciation, 25 March 1861, to a congregation of between 4,000 and 5,000, with reportedly twice that number being turned away for lack of space. The printed version ran to fifty-four pages with twenty-five additional pages of "pièces justicatives' crammed with detailed background information. ${ }^{17}$ For Dupanloup, the alleviation of poverty and famine in Ireland was a high-stakes issue that extended far beyond strictly religious considerations: 'ce n'est point une cause politique; ce n'est pas même une cause religieuse que je défends ici [...] c'est la cause même de l'humanité, de la civilisation, et des plus vives sympathies françaises'. Stressing Franco-Irish closeness ('les races du Nord et du Midi'), he argues that the Irish and the French are Catholic cousins or even sisters ('deux filles de l'Eglise Catholique'), and brothers on the battlefield. However, clearly influenced by Renan, he sees the Irish - unlike the French - as forever young, enthusiastic, honest, innocent and perhaps too generous for their own good ('peuple toujours généreux, simple et bon') - by implication an earlier and preferable version of Frenchness now lamented as lost forever in a world corrupted by wealth and vice. There are echoes here of the Irish as noble savages, ruled by emotion rather than by cold reason, with Ireland as some kind of Garden of Eden. Dupanloup's eulogy for this land of saints, scholars and missionaries, staunchly Catholic, resolutely patriotic, fills the first eighteen

17 Félix DUPANLOUP, Discours prononcé par Mgr l'Evêque d'Orléans en faveur des Pauvres Catholiques d'Irlande, à Paris dans l'Eglise Saint-Roch, le 25 mars 1861, Paris: Charles Duniol, 1861. Interestingly, a translation of this sermon was published in Dublin shortly after it was delivered in Paris: see Sermon preached by Mgr the Bishop of Orleans on behalf of the poor Catholics of Ireland in the Church of St Roch, Paris, on the Feast of the Annunciation, 1861, with a biographical note, Dublin: John F. Fowler, 1861. 
pages of this sermon and rises like a crescendo, building Ireland and the Irish up into something quite exceptional. Then comes the dramatic, killer phrase: 'Eh bien! Messieurs, voilà les hommes qui meurent de faim!'.

Irish famines past and present are evoked through a patchwork of quotations from a wide range of first and second hand reports. He stresses throughout that he knows what he is talking about as his sources are impeccable: in 1839, did he not meet the great O'Connell himself? More recent sources include a letter he has received from a village near Limerick describing recent scenes of horror and devastation. The images he conveys are deliberately provocative: he quotes a Quaker remarking in 1847 that the starving crowd surrounding him in a west of Ireland village looked more like ravenous dogs than human beings. Such use of material from the 1840s famine is interesting: it implies that notions of past and present are meaningless in Ireland as everything blends into one long endless story of famine.

Political condemnation and undisguised anger animate his commentary. He defends the Irish from accusations of laziness leading to food shortages: Irish emigrants work hard and profitably as free men and women in America: do they not send twenty-five million francs home every year? However, they are now starving in their homeland which is, scandalously, at the same time, exporting food across the world; they are starving despite being part of an opulent nation, Britain, in Europe, in a Christian setting, 'au plein soleil du XIX siècle. Voilà la vérité!'

Reaction to his sermon was intense: 'strong men were seen to shed tears; indeed, during portions of the sermon, there was hardly a dry eye in the entire church' ${ }^{18}$ The collection taken up after his sermon by nine aristocrats (including three duchesses, two countesses, a marquise and a princess) garnered between fifteen and twenty thousand francs. ${ }^{19}$

The following year, on 22 May 1862, at the recently built neo-Gothic Eglise Sainte-Clothilde, Paris, a second sermon was preached in favour of the Irish poor. This time, the orator was the Recteur of Notre-Dame in Geneva, future Cardinal and Bishop of Lausanne and Geneva, l'Abbé Gaspard Mermillod (1824-92). A printed version of this sermon (seventy pages along with a six-page preface), complete with an emblazoned crest featuring harp, shamrock, stag and castle, was published in the same year in Paris, with proceeds again going to the Irish Catholic poor. ${ }^{20}$ While the relationship between the oral and written versions of these texts is no longer clear, Mermillod himself mentions in the body of his sermon that it took him over an hour to deliver. A sense of urgency is conveyed in his statement that he was given just a

\footnotetext{
${ }^{18}$ Sermon preached by Mgr the Bishop of Orleans on behalf of the poor Catholics of Ireland in the Church of St Roch, Paris, on the Feast of the Annunciation, 1861, with a biographical note, Dublin: John F. Fowler, 1861, p. 46.

${ }^{19}$ Detail relayed by a contributor to L'Ami de la Religion who had attended the sermon, quoted in Le Courrier des Alpes, 31 March 1861, p. 3.

${ }^{20}$ Gaspard MERMILLOD, Discours prononcé par M. l'Abbé G. Mermillod, Recteur de Notre-Dame de Genève, en faveur des pauvres de l'Irlande à Paris, dans l'Eglise SainteClothilde, le jeudi 22 mai 1862, Paris: Librairie Liturgique Catholique, 1862.
} 
few days in which to prepare the sermon and that the text was hastily corrected for publication, implying that the case of the Irish poor had become too urgent to permit time spent lingering over stylistic niceties.

The genesis of Mermillod's sermon is interesting. He explains that he was asked to preach it by a spiritual and secular alliance comprising his own bishop and Dublin's Archbishop and Lord Mayor. He affords us interesting glimpses of his congregation which he describes as large, affluent and 'illustres par la naissance, par la fortune ou par le talent'. In his audience were also the 'Messeigneurs' to whom he addresses his sermon and who, according to his footnote, were Mgr Daniel McGettigan, Bishop of Raphoe, who presided the assembly, Mgr Lynch, Bishop of Toronto and Mgr Whelan, former Bishop of the Indies. His reference to their forthcoming pilgrimage to Rome suggests that Paris was a stopping place on this journey. The collection for the Irish poor, taken up at the sermon, was organised by nineteen named women ('dames') including six countesses, two princesses, four duchesses, two marquises and two maréchales, some with Celtic names (Fitz-James, Mac-Mahon, Mac'Loyd) and all with desirable addresses in central Paris. The Maréchale de Mac-Mahon listed was probably the wife of the future President of France, Patrice de Mac-Mahon.

He contextualises his sermon as just one element in a wider campaign that includes Pius IX's 1847 encyclical and Dupanloup's sermon of the previous year. $\mathrm{He}$ is at pains to justify his intervention, as a Swiss cleric, in Irish affairs. He reminds his listeners that the Swiss have much to be grateful to the Irish for: he refers to St Columbanus and to Irish foundations in St Gallen, Schaffhouse and Glaris. Perhaps his background as a Swiss Catholic makes him particularly sensitive to the presence of the Protestant Church: he introduces himself as 'un prêtre de Genève [qui] a tenté de verser un peu de baume sur la plaie que le protestantisme vainqueur a faite à l'Irlande'. As a member of the universal Catholic Church, he praises the global impact of the Irish through the work of their missionaries and through the generosity of the Irish poor in funding the building of churches worldwide.

He is at pains to highlight for his up-market and probably demanding audience the solid documentation he consulted despite having insufficient preparation time for his sermon. This includes Montalembert, Bossuet, Renan, Arthur Young, Macaulay, Thomas Moore, various reports sent to the Dublin Mansion House Committee by Catholic priests and Protestant ministers, Quaker documents, the Revue des Deux Mondes, recent editions of the Dublin Review, the Galway Vindicator and of English newspapers such as the London Times, the Morning Star, the Morning Herald, and a French cavalry officer, Edouard Déchy, who was an eloquent witness to famine in Ireland in $1847 .{ }^{21} \mathrm{He}$ makes sure to include English and Protestant sources to ensure impartiality. His main source, however, is the two-volume Etudes sur l'Irlande contemporaine, by acclaimed scholar Adolphe Louis Albert Perraud (1828-1906), Bishop of Autun, future Cardinal and member of l'Académie Française. This first-

${ }^{21}$ Edouard DECHY, Voyage en Irlande en 1846 et 1847. Misères inqualifiables, mours, caractère, usages, costumes, qualités et défauts des Irlandais et des Anglais, Paris: Comptoir des Imprimeurs Réunis, 1847. 
hand study had been published coincidentally just a few days earlier and deals at first-hand with the very recent past, $1859-62 .{ }^{22}$ Curiously, Mermillod never names the author despite lavishing praise on him, just as he mentions O'Connell ('notre cher Oratorien') without needing to name him.

From the rich collection of sources consulted, he conjures up the woes of contemporary Ireland: a difficult winter, incessant rains, food shortages in the midst of plenty, famine fever unknown anywhere else in the world, brutal and heartless evictions of young and old, prison-like workhouses that tear apart what remains of vulnerable families, emigration, proselytism, the failure of recent legislation - the list is long. Quoting from submissions made to the Mansion House Committee, he breathes life into cold statistics by describing people struggling to survive on seaweed or salted water. He hones in on details designed to raise the blood pressure of his listeners, such as Robert Peel flying in the face of evidence accepted by the international community and referring in the House of Commons in 1862 to the imaginary sufferings of the Irish. His own anger is palpable:

C'est donc en plein soleil du dix-neuvième siècle, au milieu du luxe de notre société européenne, que se passent des scènes qui rappellent involontairement ces affreuses descriptions de famine dont nos chroniqueurs du dixième et du onzième siècle ont souvent enregistré les funèbres détails.

Like the skilled rhetoretician he was, he marries fact and feeling. Playing on his audience's emotions, there is much talk of hearts jumping, lips trembling, tears flowing, groans and exclamations ringing out. He is a master of the soundbite ('votre superflu abonde, et le nécessaire vous manque!'; 'ma tâche est achevée. La vôtre commence') and of short, punchy phrases:

Les douleurs de l'Irlande, je les résume:

La pauvreté qui accable et qui tue;

Le foyer en ruines;

La famille dispersée;

La patrie perdue;

Les droits de l'honneur et parfois de la conscience en péril.

Like Dupanloup (and with Renan in the background), he presents the Irish weighed down with superlatives: ' $y$ eut-il jamais oppression plus dure de la part d'une nation civilisée? Y eut-il jamais servitude plus cruelle subie par un peuple chrétien?' At one level, he contextualises what is happening in Ireland within a religious framework, with Ireland implicitly compared to none other than Christ in agony and Mermillod, through his sermon, casting himself as Veronica wiping Christ's face. He places Ireland's woes within an international framework of antiCatholic sentiment, and calls for Catholic solidarity world-wise as a means of combatting it. If the Irish are once more without bread, this is due quite simply to their staunch, centuries-old Catholicism which, like Dupanloup, he praises, to the

${ }^{22}$ Adolphe PERRAUD, Etudes sur l'Irlande Contemporaine, 2 vol., Paris: Charles Duniol, 1862. 
extent of hailing the Virgin Mary as the 'Reine d'Irlande'. However, again like Dupanloup, he sees Ireland's cause as far more than just a religious one:

il y a la plus qu'une cause religieuse, il y a une grande infortune qui attriste et déshonore l'humanité. Devant elle, toutes les discussions doivent faire silence, toutes les colères doivent se calmer; et nous pouvons, nous devons tous nous tendre la main dans une commune et généreuse humanité.

His politics are conservative. He dismisses socialism, praises O'Connell's rejection of violence and supports the denunciation by Irish bishops of secret societies. Here as elsewhere, one suspects that his message is addressed to the French as much as to the Irish: 'le lendemain de l'émeute, le peuple n'est jamais plus avili. La révolte, comme le torrent dévastateur lorsqu'il est entré dans son cours naturel, ne laisse après elle que de la fange et des ruines'. Far from lambasting England, he lavishes praise on its Queen and on occasional examples of English decency and outrage at what was happening in its colony. Indeed, he points to the difficulty of garnering international support for Ireland given the high status of Ireland's oppressor ('le modèle de civilisation du XIX siècle'): if Austria or Russia were to do what England is doing, this task would be easier. He skilfully flips such backhanded compliments into criticism: how could such a civilised country allow Ireland to be racked by famine yet again? Linking Ireland and Poland, "les drapeaux de saint Casimir et de saint Patrice', he invites his audience to imagine the appalling (but thankfully unlikely) vista whereby these difficult political times 'où les politiques les plus habiles sentent avec effroi le sol trembler' might witness a European conflagration if the tinderboxes that are Ireland and Poland were to espouse violence: 'ce qui est le bouclier protecteur de l'Europe, c'est l'Irlande et la Pologne gardées pures sous la bénédiction de Pie IX'.

He lambasts modernity and what he sees as contemporary values: 'l'or est le but universel, et quiconque l'atteint a fait son salut'. The industrial revolution leads to decadence and spiritual impoverishment: 'la tristesse vous gagne, la mélancolie vous accable, le froid vous saisit, le paupérisme est dans les âmes malgré la fascination de votre prospérité extérieure!' At a practical level, the current gold rush risks fostering social and political unrest:

L'épaisse fumée de l'industrie cache aux regards de l'ouvrier le ciel qui doit être son espoir et son repos; alors, il se forme dans les profondeurs de ces âmes un ferment d'âpres cupidités. A travers ce qu'il nomme les barreaux de sa misère et de ses labeurs, le travailleur se prend à jeter un regard d'envie sur l'or qu'il n'a pas, et il maudit la poussière et la sueur de sa pauvreté.

In this context, he raises up the Irish as a people apart, a role model for other nations. The Irish have their priorities right; for them, what counts is the next life, this life is merely 'l'antichambre du paradis'. Through their suffering and persecution (which he welcomes on their behalf!), the Irish have become better Christians, stronger and more noble: 
quel plus sublime spectacle qu'un peuple renonçant à tout ce qui est du temps pour garder ce qui est d'éternité? [...] et pour nos cœurs blasés par une civilisation artificielle, n'est-ce pas un charme de contempler ce vivant souvenir du moyen age? N'y a-t-il pas pour nos âmes fatiguées du matérialisme contemporain, une sainte émotion à regarder ce peuple, au milieu de ses plaines, de ses rochers et de ses montagnes, fidèle à sa langue, à son histoire, à son caractère national, mais plus fidèle encore à ce qui fait sa force, son lien, sa tradition, ce qu'il aime comme son trésor et sa vraie fortune, sa foi?

He has seen the future and it will be glorious: a peaceful international Catholic alliance is about to emerge, with destitute Ireland to the forefront, a beacon of light in a world of shadows, a role model guiding sophisticated France and the rest of the world, with a newly converted England (having seen the error of her Protestant ways...) safely back within the Catholic fold once more.

\section{0}

A mere eight years later, in 1880, with a dispiriting sense of l'éternel retour as Ireland was threatened by yet another famine, French episcopal letters and a sermon preached in central Paris called once more for famine relief for Ireland. The Bibliothèque Nationale de France holds three such letters. ${ }^{23}$ The earliest of these, dated 11 February 1880, runs to eleven pages and was penned by the Bishop of Autun, Chalon and Toul, who transpires to be none other than Adolphe Perraud, author of the two-volume 1862 study, Etudes sur l'Irlande contemporaine, that informed Mermillod's sermon in 1862. Like other writers, Perraud sees his work as part of the ongoing famine relief campaign for Ireland alongside the Pope's 1847 encyclical and the sermons of Dupanloup (1861) and Mermillod (1862) which he mentions. He emphasises the relentlessness of famine in Ireland: 1847, 1860 and again now. Like other writers, he seems embarrassed at asking for alms especially for a foreign nation at such difficult times. However, he advances Irish exceptionalism in his defence: while other parts of Europe may suffer from poor harvests and inclement weather, this is merely a passing inconvenience ('une gêne momentanée') compared to famines in Ireland. Christian charity dictates that one must help others in need, and did the French not send generous famine relief to India three years earlier? However, there is something different and special about the Irish case. For one thing, Franco-Irish links are particularly strong: he even suggests that St Patrick and St Martin de Tours were cousins. Within Europe, Ireland and Poland have always been exceptionally close to France: France sees them as her sisters, with Ireland as her 'sœur en deuil'. Now that everyone else is rallying to help the starving Irish - just a few days earlier, Pope Leo XII sent ten thousand francs to Ireland; America and England are sending contributions to the Irish Catholic bishops - now comes France's turn. Catastrophe threatens: monies must collected as fast as possible: 'donner vite, c'est donner deux fois'.

\footnotetext{
${ }^{23}$ I am immensely grateful to Professor Christophe Gillissen for taking the trouble to procure copies of this rare material for me from the BNF. Please see appendix 2 infra for bibliographical details.
} 
Famine in Ireland is, Perraud implies, a subject he knows all too well. His 1860 field visit to Ireland which resulted in a one thousand-page closely argued study, with a phalanx of footnotes and appendices, took up two years of his life, an assertion borne out by even a quick perusal of this work. He explains here that, in fact, in 1860, at the age of thirty two, he was sent to Ireland to investigate not just the impact but also the causes of the 'souffrances séculaires' of the Irish. Words fail him when he tries to evoke the poor, desolate landscapes of the west of Ireland in all its misery compounded by policies imposed by Cromwell and others. In fact, had he not seen them at first hand, he would dismiss such descriptions as fantasy. He cannot forget witnessing in Gweedore, in remote Donegal, mothers collecting seaweed with no nutritional value but which served to satiate empty stomachs. Interestingly, he adds that he has received letters from these remote regions again in recent days with more worrying news.

Just one week later, on 18 February 1880, the Archbishop of Tours addressed a strongly-worded three-page appeal to his clergy ordering a collection for Irish famine victims. He expresses himself succinctly from the very first line, starting in medias res:

Une épouvantable famine ravage en ce moment l'Irlande. Les pluies continuelles de l'année dernière y ont fait complètement manquer la récolte de pommes de terre, dont les pauvres font leur seule nourriture. Les comtés de l'Ouest et quelques-uns du Sud et du Nord sont, par suite, dans un état de misère inconcevable. Là où ils ne meurent pas de faim, ils n'ont pour vivre que la farine de maïs, dont ils font une espèce de bouillie avec de l'eau; encore ne peuvent-ils pas toujours se procurer cette nourriture si peu substantielle. Ils n'ont plus de crédit et ne trouvent rien à gagner par leur travail.

Further problems include no proper clothing, no heating as turf is sodden due to endless rains. As in other appeals, the writer hesitates to ask for further alms given that difficulties at home caused by bad weather, but Ireland's present situation is 'un cas exceptionnel'.

The following month, on 28 March 1880, in a four-page pastoral letter, the Bishop of Moulins ordered a collection for Irish famine victims. Along with the many elements covered in the other letters, he stresses Ireland's role as an example to be followed ('l'exemple d'une hérö̈que, invincible, unanime résistance aux séductions de l'hérésie et de l'impiété'), and suggests that charity given now could generate divine reward in this life and in the next. Each of these three letters ends with instructions ordering that it be read from the pulpit in all churches and chapels in the diocese in question on a named Sunday, with a collection for Irish famine victims to be taken up on the following Sunday.

Just three weeks later, on 18 April 1880, in the imposing Eglise de la Madeleine in central Paris, le Père Jacques-Marie-Louis Monsabré (1827-1907), a Dominican famous for his fiery homilies, preached a sermon on behalf of Irish famine victims. The thirty-page printed version of this oration, priced at 1 franc 50 centimes, and sold on behalf of Irish famine victims, mentions on its cover the Irish 
College at the rue des Irlandais. ${ }^{24}$ The high status of this public event is clear: the Cardinal-Archbishop of Paris, Joseph Hippolyte Guibert, presided over it, and seventeen society ladies organised the collection. While fewer aristocrats feature on this list than on Mermillod's, it nonetheless comprised one princess, two marquises, one baronne, one duchess, one countess and a maréchale. There is a certain overlap between the names of the collectors attending the three sermons. As with the two earlier sermons, some of these women had Celtic surnames (Mac-Kay, Connolly, Mac-Mahon). The monies collected from this sermon were be forwarded to the Dublin Mansion House Committee, presided by the Lord Mayor of Dublin.

Monsabré locates himself within a network of similar pro-Irish speakers including Dupanloup and Mermillod. He legitimises his call for help for the Irish by recalling that the world has much to be grateful to them for. Was it not the wandering Irish who, like the Jews of old, banished from their homeland by persecution, brought Catholicism to countries like Australia? Is there not a chance that England may revert to Catholicism thanks to the Catholic Emancipation Bill of 'le grand O'Connell'? But why specifically should France help the Irish? Stressing strong, age-old Franco-Irish links, he reminds his listeners that over half a million Irish people died for France. Many of their descendants have risen to fame and glory in the service of France. He lists scores of Irish leaders in French battalions such as the Brigade irlandaise (1690-1792) and the Légion irlandaise (1803-1814). Even within living memory, did the Irish not contribute to alleviate disasters in France, including flooding in the Loire, the Rhone and the Garonne, and the Limoges fire of 1864? More than that, however, under the skin the Irish and French are two of a kind, like siblings separated at birth. Echoing Renan and centuries of French writings on Ireland, he showers praise on both the Irish and on his audience: 'Comme le Français, l'Irlandais est vif, ardent, imaginatif, expansif, généreux et même un peu batailleur. Il parle volontiers et avec éloquence, et les impétueuses saillies de sa gaieté le mettent promptement d'accord avec notre joyeux tempérament.'

While Ireland is the 'victime choisie par la Providence, ce pauvre sublime [...] prédestiné à tous les malheurs', this current situation is particularly catastrophic, as bad as the famine of 1847 perhaps. His warnings are stark: tomorrow, Ireland will be 'l'hécatombe de ceux qui n'auront pas le moyen de fuir'. Quoting from the 1880 Proceedings of the Mansion House Committee for the relief of distress in Ireland, he summarises: 'le cœur saigne à la lecture des lettres et des rapports qui peignent ses souffrances de l'heure présente et ses angoisses en face de l'avenir'.

Like others evoked earlier, he struggles to understand how a people can starve in a land of plenty and, alongside English Protestantism, lists realities such as absentee landlords, land agents and taxes, proving that he is very well informed on the situation in Ireland, a country he had already visited in any case as he mentions in passing. However, he deliberately sidesteps obvious political answers: 'point d'accusations, point de récriminations; soyons tout à la miséricorde'.

${ }^{24}$ Jacques-Marie-Louis MONSABRE, Pour l'Irlande: Allocution prononcée dans l'Eglise de la Madeleine à Paris, le 18 avril 1880, Paris: Librairie Liturgique Catholique / E. et A. Lesort, 1880. 
He praises the French (including, of course, his audience whom he is hoping to sway) by recalling how, crushed by the Penal Laws, the Irish have always been sure to find a safe haven in France. Like Mermillod, he expresses pride that it is to France that Ireland has always turned in her hour of need, as this reinforces his image of his homeland as charitable and generous. Indeed, his essentialist reading of his fellow country people sees charity hardwired within them: 'vous n'auriez pas le cour français, si vous n'étiez pas touchés de cette navrante misère!' Hence, his references to France's famed charity in other recent disasters including disease, floods, fires and famine in India, the New World, Austria and Spain. Then comes his resounding challenge to his listeners:

\section{L'Irlande affamée ne sera pas oubliée. Déjà de généreuses inscriptions ont été ouvertes en sa faveur sur différents points de la France. Le diocèse de Paris va compléter aujourd'hui la sienne par une quête qui, je l'espère, méritera d'être inscrite en chiffres majuscules dans les annales de la charité.}

At the heart of these 1880 appeals lie little known but evocative illustrations of Franco-Irish solidarity from the time of the Franco-Prussian War less than a decade earlier and which are seized upon in order to further pressurise the French faithful into supporting the Irish. At one level, the key humanitarian role played by the Irish Ambulance from its arrival in Le Havre in October 1870 onwards is acknowledged by Monsabré. At another lesser known but perhaps more resonant level, the massive fund-raising campaign organised by the Irish to help French civilians and war victims during the $1870-71$ conflict is also remembered. ${ }^{25}$ In fact, colossal quantities of war relief, including money, food such as preserved meat, condensed milk and sacks of potatoes, clothing, old bed linen for use as bandages, poured into France especially from the poorer people of Cork city and county during the FrancoPrussian War. This initiative was so fruitful that in October 1870 some of the largesse sent by the people of Cork was put on public display in Caen for the perusal of its astonished citizenry. These details dovetail with Monsabré's assertions: alongside his reference to 200,000 francs sent by the Irish during the war to Félix Dupanloup, Bishop of Orleans, he adds: 'Au Nord, à l'Ouest, au Centre, on se rappelle les instruments de chirurgie, le linge, les vêtements, les chaussures, les viandes conservées, les farines, les semonces, l'argent, distribués par les soins du comité irlandais'. The Bishop of Tours, for his part, quotes at length in his letter from the first-hand testimony of his predecessor in that bishopric, Joseph Hippolyte Guibert, now Cardinal-Archbishop of Paris, to the effect that it was the poorest of the poor in Ireland who sent him and his fellow bishops considerable amounts of money for the relief of suffering during the war a decade earlier when his dioceses was a warzone. Monsabré surmises that the presence of the aforementioned Cardinal-Archbishop Guibert presiding over his sermon in the Eglise de la Madeleine was his way of thanking the Irish for their generosity.

\footnotetext{
${ }^{25}$ See however Grace NEVILLE, 'The People's War? Cork, Ireland and the Franco-Prussian War (1870-71), pp. 47-68 in Yann BEVANT, Anne GOARZIN and Grace NEVILLE (eds.), France, Ireland and Rebellion, vol. 2, Rennes: CRBC / Universite de Rennes 2, 2011.
} 
For Monsabré, the visceral identification of the Irish with the French was further intensified by the Franco-Prussian: while other countries stood idly by, Ireland helped the French 'comme si sa propre vie était menacée. A chaque annonce de nos désastres, elle souffrait et gémissait comme nous. Partout une tristesse profonde et une fiévreuse préoccupation'. He adds that, during the conflict, Irish newspapers ran three or four daily editions to bring out the latest war news, and that they referred to the French as 'nous'. A perusal of sources such as the Cork Examiner bears out Monsabré's contentions. Astonishing as it may seem, the Franco-Prussian war was the main story on the front page of the Cork Examiner throughout the entire conflict. It is dissected in every edition, day-by-day, battle by battle, event by event, with in-depth reporting and analysis through words and maps from the previous day. The obsession of the people of Cork with the FrancoPrussian War is clear from the words of the ex-High Sheriff of Cork from February 1871: 'the terrible sufferings of the French [are] present in [our] minds night as well as day - [our] last thoughts going to bed and [our] first on rising in the morning was the condition of the French - whether their position would or had changed for the better or worse, ${ }^{26}$

Why the Irish, and particularly the people of Cork, should have responded with such overwhelming generosity to the French in 1870-71 is not immediately clear and has received little scholarly attention. However, a close reading of the Cork Examiner over the period in question furnishes a possible answer. Especially in Cork which had been so ravaged by famine, survivors of famine and their descendants remembered how, not long before, the French had come to their help when they were starving. It is clear that for these people, this was now payback time, payback not just for everything the French had given them over the centuries but most especially for their help within living memory. A French priest preaching on behalf of his countrymen and women in the little market town of Macroom in February 1871 noted that, during his sermon, people sighed and cried openly. ${ }^{27}$ Many of these people had possibly never travelled as far as Cork city, just 39 kilometres away. Yet, men and women, they were moved to tears at the mere thought of the sufferings currently experienced by the French. It is surely not fanciful to suggest that they were moved not just by the evocation of the difficulties the French were currently undergoing, but also by their own recent trauma that still lingered in their bones, and by the memory of French solidarity that had helped to keep them alive.

As in the 1840s, these later fund-raising drives were also organised in Quebec. In the early 1880s, probably in 1884, the Quebec-born Jean Langevin (1821-1892), first bishop of the dioceses of Rimouski in Quebec, addressed a Lettre pastorale en faveur de l'Irlande to his clergy across the dioceses in his vast 150,000 square mile bishopric. $^{28}$

\footnotetext{
${ }^{26}$ Cork Examiner, 28 February 1871.

${ }^{27}$ Ibid., 15 February 1871.

${ }^{28}$ A copy of this letter exists in the British Library, London. I have unfortunately not been able to consult it yet.
} 


\section{Conclusion}

French awareness of famines in Ireland, though a neglected topic, threads through much French literature from the 1840 s down to our own time. ${ }^{29}$ In the 1840 s, it features right across the span of French writing, from classical authors like Balzac to writers of Parisian boulevard theatre for non-literate audiences. In more recent times, it surfaces in the work of eminent writers such as Max Jacob (18761944) and Michel Tournier (b. 1924). The mystery as to how so many fiction writers especially in mid- and late-nineteenth century France knew so much about famine in a faraway country is surely cleared up by the uncovering of the texts analysed earlier: they make it clear that from the 1840 s to the 1880 s it would have been near nigh impossible for anyone anywhere in France - a highly educated city dweller or an illiterate peasant in la France profonde - to escape the French Catholic Church's blanket coverage of the topic of famine in Ireland.

The texts analysed here raise many questions not answered this short study. What percentage of the French public between the 1840s and the 1880s was literate? How many of them would have had to rely on oral expositions of famine in Ireland? What percentage of them were Catholic church-goers? How many of them understood French? Were these letters, when transformed into sermons, transmitted in regional languages? What was the exact relationship between the spoken and written versions of these appeals? What specifically became of the vast sums of French money raised for famine relief in Ireland? And what about the close and often unexpected underground links binding so many of the speakers? These and other related questions give an indication of the depths and unfolding layers of interest and interpretation to be found in the texts under discussion here.

The modern reader, suffering perhaps from compassion fatigue, sceptical of tele-evangelists, may approach appeals like those reported above with some understandable wariness. However, with their powerful eloquence, skilled rhetoric and urgent, near panic-stricken warnings of impending disaster, it is surely difficult to dismiss them or to treat them with indifference. Far from some box-ticking exercise completed under duress to comply with some papal instruction, they resonate with personal conviction and convey deep empathy with the pitiful plight of a people yet again on its knees. In remembering the French famine aid that was generated by initiatives like those outlined above, Michael Donegan, the County Cork farmer quoted earlier, was acknowledging that the faraway French were often more dependable and more truly Christian than fellow country men and women closer to home from whom some semblance of charity could legitimately have been expected, but which was cruelly missing when it was needed most.

\section{For Dermot Keogh, homage, amitiés}

\footnotetext{
${ }^{29}$ Grace NEVILLE, 'Cette contrée qui souffre: French Literature and the Great Irish Famine', unpublished research paper, European Research Council-funded conference on 'Global Legacies of the Great Irish Famine: Transnational and Interdisciplinary Perspectives', Radboud University Nijmegen, The Netherlands, 28 March 2013.
} 


\section{Appendix 1}

Mandement de Monseigneur l'Evêque d'Angers qui réclame des prières et des aumônes en faveur de l'Irlande, Angers, 1847.

Mandement de Son Eminence Monseigneur le Cardinal Evêque d'Arras, qui ordonne des prières en faveur de l'Irlande et invite à la secourir de quelques aumônes, Arras, 1847.

Mandement de Monseigneur l'Evêque de Beauvais qui publie l'encyclique de Pie IX, pour demander des prières et des secours en faveur de l'Irlande, Beauvais, 1847.

Mandement de Monseigneur l'Archevêque de Bordeaux, qui publie l'encyclique de Pie IX, pour demander des prières et des secours en faveur de l'Irlande, Bordeaux, 1847.

Mandement de Monseigneur l'Evêque de Carcassonne qui publie l'encyclique adressée par Pie IX pour demander des prières et des secours en faveur de l'Irlande, Carcassonne, 1847.

Mandement de Monseigneur l'Evêque du Mans, qui publie l'encyclique de Pie IX, pour demander des prières et des secours en faveur de l'Irlande, Le Mans, 1847.

Mandement de Monseigneur l'Evêque de Limoges, à l'occasion de l'encyclique adressée par Pie IX pour demander des prières et des secours en faveur de l'Irlande, Limoges, 1847.

Mandement de Son Eminence le Cardinal de Bonald, Archevêque de Lyon et de Vienne, qui publie l'encyclique adressée par Pie IX pour demander des prières et des secours en faveur de l'Irlande, Lyon, 1847.

Mandement de Monseigneur l'Evêque de Marseille qui ordonne une quête pour les pauvres de l'Irlande, Marseille, 1847.

Mandement de Monseigneur l'Evêque de Mende qui publie l'encyclique adressée par Pie IX pour demander des prières et des aumônes en faveur de l'Irlande, Mende, 1847.

Mandement de Monseigneur l'Evêque de Metz qui prescrit des prières et demande des secours en faveur de l'Irlande, Metz, 1847.

Mandement de Monseigneur l'Evêque de Nancy et de Toul qui publie l'encyclique adressée par Pie IX pour demander des prières et des secours en faveur de l'Irlande, Nancy, 1847.

Mandement de Monseigneur l'Evêque de Pamiers qui publie l'encyclique adressée par Pie IX pour demander des prières et des secours en faveur de l'Irlande, Pamiers, 1847.

Mandement de Monseigneur l'Archevêque de Paris qui publie l'encyclique de Pie IX pour demander des prières et des secours en faveur de l'Irlande, Paris, 1847.

Mandement de Monseigneur l'Evêque de Perpignan qui publie l'encyclique adressée par Pie IX pour demander des prières et des secours en faveur de l'Irlande, Perpignan, 1847.

Mandement de Monseigneur l'Evêque de Soissons et Laon qui publie l'encyclique adressée par Pie IX pour demander des prières et des secours en faveur de l'Irlande, Soissons, 1847. 
Mandement de Monseigneur l'Evêque de Strasbourg qui publie l'encyclique adressée par Pie IX pour demander des prières et des secours en faveur de l'Irlande, Strasbourg, 1847.

\section{Appendix 2}

Lettre pastorale de Monseigneur l'Evêque d'Autun, Chalon et Macon au clergé et aux fidèles de son diocèse prescrivant une quête pour les populations de l'Irlande affligées par la famine, Autun, 11 February 1880.

Lettre circulaire de Monseigneur l'Archevêque de Tours prescrivant une quête pour les victimes de la famine en Irlande, Tours, 18 February 1880.

Lettre pastorale de mandement de Monseigneur l'Evêque de Moulins prescrivant une quête pour les victimes de la famine en Irlande, Moulins, 28 March 1880.

\section{Bibliography}

BEAUMONT, Gustave de. L'Irlande sociale, politique et religieuse. Paris: Michel Levy frères, 1839.

BLANC, Louis. Lettres sur l'Angleterre. Paris: A. Lacroix, Verboeckhoven et cie, 1866, vol. 2 .

Cork Examiner, 1870-71.

DECHY, Edouard. Voyage en Irlande en 1846 et 1847. Misères inqualifiables, mours, caractère, usages, costumes, qualités et défauts des Irlandais et des Anglais. Paris: Comptoir des Imprimeurs Réunis, 1847.

Extraits de quelques lettres de NN. SS. Les archevêques et évêques d'Irlande, à Monsieur O'Carroll, correspondent du Comité de Secours, Paris: Imprimerie d'A. Sirou et Desquers, 1847.

GALIBERT, Léon and Clément PELLET. Angleterre, Ecosse et Irlande. Paris: Firmin, Didot frères, 1844.

GARNIER, Adolphe. De la peine de mort. Paris: Imprimerie de Guiraudet, 1827.

KINEALY, Christine. Charity and the Great Hunger in Ireland. London:

Bloomsbury, 2013.

de LASTEURIE, Jules. 'L'Irlande depuis la dernière famine', Revue des deux mondes, August 1853.

Lettre pastorale de Monseigneur l'Evêque de Montréal pour publier l'encyclique de Notre Saint père le Pape Pie IX en faveur de la malheureuse Irlande, Montreal, 1847.

$<$ www.memoireetactualite.org/fr/presse_resultats.php?rs_kw=irlande+famine\&searc htype $=\mathrm{S}>$

MERMILLOD, Gaspard. Discours prononcé par M. l'Abbé G. Mermillod, Recteur de Notre-Dame de Genève, en faveur des pauvres de l'Irlande à Paris, dans l'Eglise Sainte-Clothilde, le jeudi 22 mai 1862. Paris: Librairie Liturgique Catholique, 1862. 
MONSABRE, Jacques-Marie-Louis. Pour l'Irlande: Allocution prononcée dans l'Eglise de la Madeleine à Paris, le 18 avril 1880. Paris: Librairie Liturgique Catholique / E. et A. Lesort, 1880.

NEVILLE, Grace. 'The People's War? Cork, Ireland and the Franco-Prussian War (1870-71)', pp. 47-68 in Yann BEVANT, Anne GOARZIN and Grace NEVILLE (eds.), France, Ireland and Rebellion, vol. 2, Rennes: CRBC / Université de Rennes 2,2011 .

. 'Remembering and Forgetting the Great Famine in France and Ireland', New Hibernia Review, vol. 4, no. 16, winter 2012, pp. 80-94.

'Cette contrée qui souffre: French Literature and the Great Irish Famine', unpublished research paper, European Research Council-funded conference on 'Global Legacies of the Great Irish Famine: Transnational and Interdisciplinary Perspectives', Radboud University Nijmegen, The Netherlands, 28 March 2013.

NI CHEARBHAILL, Maire Brighid. 'The Society of St Vincent de Paul in Dublin, 1926-1976'. PhD dissertation, National University of Ireland, Maynooth, 2008.

$<$ www.papapencyclicals.net/Pius09/p9praede.htm>

PERRAUD, Adolphe. Etudes sur l'Irlande Contemporaine. Paris: Charles Duniol, 2 volumes, 1862.

Rapport à Messeigneurs les archevêques et évêques de France et à messieurs les membres du Comité d'Irlande. Paris: Imprimerie de Jules-Judeau, 1849.

Sermon preached by Mgr the Bishop of Orleans on behalf of the poor Catholics of Ireland in the Church of St Roch, Paris, on the Feast of the Annunciation, 1861, with a biographical note. Dublin: John F. Fowler, 1861.

WALSH, Joseph Alexis le Vicomte. Yvon le Breton ou souvenirs d'un soldat des armées catholiques et royales. Paris: J. Vermot, 1854. 



\title{
'And this in thriving and prosperous Antrim!': An Anglo-Irish landlord's perspective on the Famine
}

\author{
Wesley HUTCHINSON \\ Université Sorbonne Nouvelle
}

The quotation in the title of this paper is taken from a pamphlet by an AngloIrish landlord, Alexander Shafto Adair, entitled The Winter of 1846-7 in Antrim, with Remarks on Out-door Relief and Colonization, published in London in 1847. ${ }^{1}$

Adair's family connections with Antrim went back to the beginning of the seventeenth century. The Adairs, who owned the Kinhilt estate in the Galloway peninsula (south-west Scotland), acquired land in the area of Ballymena (County Antrim) in $1618,{ }^{2}$ around the same time that many other English and Scottish settlers were arriving in the escheated counties of Ulster under the terms of the Crownsponsored Plantation scheme. The family subsequently gave up its land in Scotland and settled permanently in Ireland, before acquiring an estate at Flixton Hall in Suffolk in 1783 which was to become for a long time the principal family seat. Robert Alexander Shafto Adair (1811-1886), the author of the pamphlet, was educated at Harrow and Cambridge. Having made a number of visits to Ballymena from 1840 on, he moved there in 1846 to administer the estate on behalf of his father. He arrived therefore just as the effects of the famine were about to reach catastrophic proportions. A Whig, he was elected to a constituency in Cambridge at the general elections in 1847 , the year his pamphlet on the famine in Ireland was published.

\footnotetext{
${ }^{1}$ Alexander Shafto ADAIR, The Winter of 1846-7 in Antrim, with Remarks on Out-door Relief and Colonization, London: James Ridgway, 1847, 70 pp. The text, with a foreword by Brian Logan, was re-edited by Eull Dunlop in 1997 and published by the Mid-Antrim Historical Group (Alexander Shafto ADAIR, The Winter of 1846-7 in Antrim, with Remarks on Out-door Relief and Colonization, ed. Eull DUNLOP, Ballymena: Mid-Antrim Historical Group, 1997, 24 pp). In acknowledgement of his extraordinarily valuable work in identifying and salvaging material highlighting key aspects of the local history of the Mid-Antrim area, page references (in brackets) will be to Dunlop's 1997 edition. I would also like to thank Liz Hoy of the Local Studies Department of Ballymena Library for her generous assistance during the preparation of this article. The quotation used as the title of this article is on page 21 of Dunlop's re-edition.

${ }^{2}$ Local historians and commentators differ on the details of the early history of the Adairs. Brian LOGAN, in Ballymena during the Famine (Ballymena, 2000, p. 5), says that the estate was acquired 'about 1618' from a local Irish lord, Rory Oge McQuillan, while Nicola PIERCE, in Ballymena: City of the Seven Towers [2007] (Belfast: Brehon, 2011, p. 18), says the Adairs 'exchanged Dunskey Castle [near Portpatrick, Scotland] for lands in Ballymena that were owned by Viscount Montgomery of Ardes' in 1608.
} 